\title{
The Experiment Study of Biogas Atomization Upgrading with Water Scrubbing at Atmospheric Pressure
}

\author{
Hongchao GENG \\ Soochow University, Suzhou, Jiangsu, China \\ Qidong CHEN \& Genlin ZHAO \\ Changshu Institute of Technology, Changshu, Jiangsu, China
}

\begin{abstract}
We developed a set of equipments used in biogas upgrading with water scrubbing. The paper analyzed the working principle of biogas atomization upgrading with water scrubbing and researched key process by a lot of experiments. We solved four key technical problems of the biogas upgrading system: the best gas-water ratio, suitable temperature range, suitable biogas engineering scale, the purification efficiency and energy consumption. The experimental results showed that equipment investments of the biogas upgrading system are small, the $\mathrm{CH}_{4}$ concentration in biogas can be as high as $77 \%$ after upgrading, energy consumption of processing $1 \mathrm{Nm}^{3}$ biogas is less than $0.35 \mathrm{~kW} \cdot \mathrm{h}$, the economic processing is $6 \sim 20 \mathrm{~m}^{3} / \mathrm{h}$. This system is suitable for the household biogas digester and could be also used as a pretreatment system of largescale engineer of biogas upgrading at high pressure.

KEYWORD: Biogas upgrading; Water scrubbing; Gas atomization distributor; Water temperature; gas-water ratio; Energy consumption
\end{abstract}

\section{INTRODUCTION}

The double crises of the energy and the environment make the research and development of renewable energy become a focus of study in the world (Cheng et al. 2008). Biogas, as a kind of renewable and clean energy, can be produced by anaerobic fermentation from organic waste. In recent years, biogas engineering attracts more and more attention of China. The implementation of many preferential policies accelerates the development of biogas project in China. At present, biogas produced from large and medium-sized biogas projects is mainly used for heating and cogeneration in China. How to get a high value use of biogas and make greater economic benefit are the key to normal operation and sustainable development of the biogas projects (Chen et al. 2010).

Biogas becomes bio-methane after upgrading, which can replace natural gas, inject into natural gas grid and be used as vehicle fuel. So biogas has massive potential for development. At present, the technology of biogas upgrading for bio-methane has been mature in Sweden, Germany and other western developed countries. In recent years, our country also carried out a series of research works about technologies and equipments of biogas upgrading, the works are mainly focused on the chemical absorption and physical adsorption, and China have developed the commercialization of purification equipments (Zheng \& Zhang. 2013). However, the research works are not enough in the field of water scrubbing. Based on the actual production conditions, we researched the technology of biogas atomization upgrading with water scrubbing in atmospheric pressure, analyzed the principle of upgrading and the main influencing factors. And we made a lot of experiments and analyzed experimental results. The test data can be applied to production practice directly, so there is a practical guiding significance.

\section{MATERIALS AND METHODS}

\subsection{The solubility of $\mathrm{CO}_{2}$ and $\mathrm{CH}_{4}$ in water}

At atmospheric pressure, $\mathrm{CH}_{4}$ is almost insoluble in water. But $\mathrm{CO}_{2}$ dissolves in water and some reacts with water, producing $\mathrm{H}_{2} \mathrm{CO}_{3}$ which then ionizes. At the temperature of $25.5^{\circ} \mathrm{C}$ and the pressure of an atmosphere, the total amounts of $\mathrm{H}_{2} \mathrm{CO}_{3}$ and $\mathrm{HCO}_{3}{ }^{-}$ are only about $0.6 \%$ of the amounts of $\mathrm{CO}_{2}$ dissolved in water, so the physical absorption of $\mathrm{CO}_{2}$ in water accounts for absolute position and the generation and ionization of $\mathrm{H}_{2} \mathrm{CO}_{3}$ can be negligible (Ma. 2009). So the solubility of $\mathrm{CO}_{2}$ can be described by Henry's law in water at the 
atmosphere pressure. Henry's law is shown in formula 1 (Song et al. 1992):

$$
P^{*}=E \cdot x
$$

In the formula $1, P^{*}$ is partial pressure of gas; $E$ is Henry's constant; $x$ is the mole fraction of gas in solution.
As showing in Table 1 , at $25^{\circ} \mathrm{C}$ and an atmosphere in water, the Henry's constant of $\mathrm{CH}_{4}$ is 25 times than $\mathrm{CO}_{2}$ in pure water, which means that the solubility of $\mathrm{CO}_{2}$ is 25 times than $\mathrm{CH}_{4}$, so the solubility of $\mathrm{CH}_{4}$ can be neglected at the atmospheric pressure.

Table 1 . At the atmospheric pressure, Henry's constant of $\mathrm{CO}_{2}$ and $\mathrm{CH}_{4}$ in pure water

\begin{tabular}{|c|c|c|c|c|c|c|c|}
\hline$E \times 10^{-5}(\mathrm{kPa})$ & $0{ }^{\circ} \mathrm{C}$ & $5^{\circ} \mathrm{C}$ & $10^{\circ} \mathrm{C}$ & $15^{\circ} \mathrm{C}$ & $20^{\circ} \mathrm{C}$ & $25^{\circ} \mathrm{C}$ & $30^{\circ} \mathrm{C}$ \\
\hline $\mathrm{CO}_{2}$ & 0.738 & 0.888 & 1.05 & 1.24 & 1.44 & 1.66 & 1.88 \\
\hline $\mathrm{CH}_{4}$ & 22.7 & 26.1 & 30.1 & 34.1 & 38.1 & 41.8 & 45.5 \\
\hline
\end{tabular}

\subsection{Mass transfer of $\mathrm{CO}_{2}$ in water}

The principle Biogas atomization upgrading with water is that using water to absorb $\mathrm{CO}_{2}$ in the biogas. Water absorbing $\mathrm{CO}_{2}$ is a process of mass transfer between gas and liquid. Over the years, some scholars put forward a variety theories of mass transfer, there are two-film theory, solute osmosis theory and surface renewal theory mainly. One of the most representative theories is two-film theory, which was put forward by Whiteman in 1923 (Jia \& Chai. 2013).

According to the two-film theory, total resistances of gas absorption process are gas film resistance and liquid film resistance. Water absorbing $\mathrm{CO}_{2}$ is regarded as controlling by liquid film, and $K_{L} \approx k_{L}$. The mass transfer rate per unit area in liquid film is shown in formula 2 :

$$
N_{A}=k_{L}\left(C_{i}-C\right) \approx k_{L}\left(C^{*}-C\right)
$$

In the formula $2, N_{\mathrm{A}}$ is mass transfer rate; $k_{L}$ is absorption coefficient in liquid film; $C_{i}$ is the concentration of the solute at interface; $C^{*}$ is saturation concentration in liquid when the gas partial pressure is $P^{*} ; C$ is the solute concentration in liquid.

\subsection{Upgrading process}

Before upgrading, water almost fills with the upgrading tower (Fig. 1). When the upgrading process starts, biogas is transported into the bottom of upgrading tower and divided into a lot of small bubbles. The bubbles are distributed uniformly in water. Water flows into tower from the top. Adjust the throttle valve to keep balance of water. When Biogas bubbles are rising, $\mathrm{CO}_{2}$ dissolves in the water. Biogas bubbles become smaller, and then break up when the bubbles rise to water surface. $\mathrm{CH}_{4}$ and $\mathrm{CO}_{2}$ in bubbles are released, while $\mathrm{CO}_{2}$ decreases and $\mathrm{CH}_{4}$ increases relatively at this time and biogas is purified. Waste water containing $\mathrm{CO}_{2}$ is collected and regenerated by the air blowing

\subsection{Main equipments of biogas upgrading system}

The main equipments of biogas upgrading system include desulfurizing tower, roots blower, upgrading tower and gas atomization distributor. Atomization distributor installs in the bottom of upgrading. The inside of the upgrading tower fills with polypropylene ladder ring packing, whose outside diameter is $50 \mathrm{~mm}$.

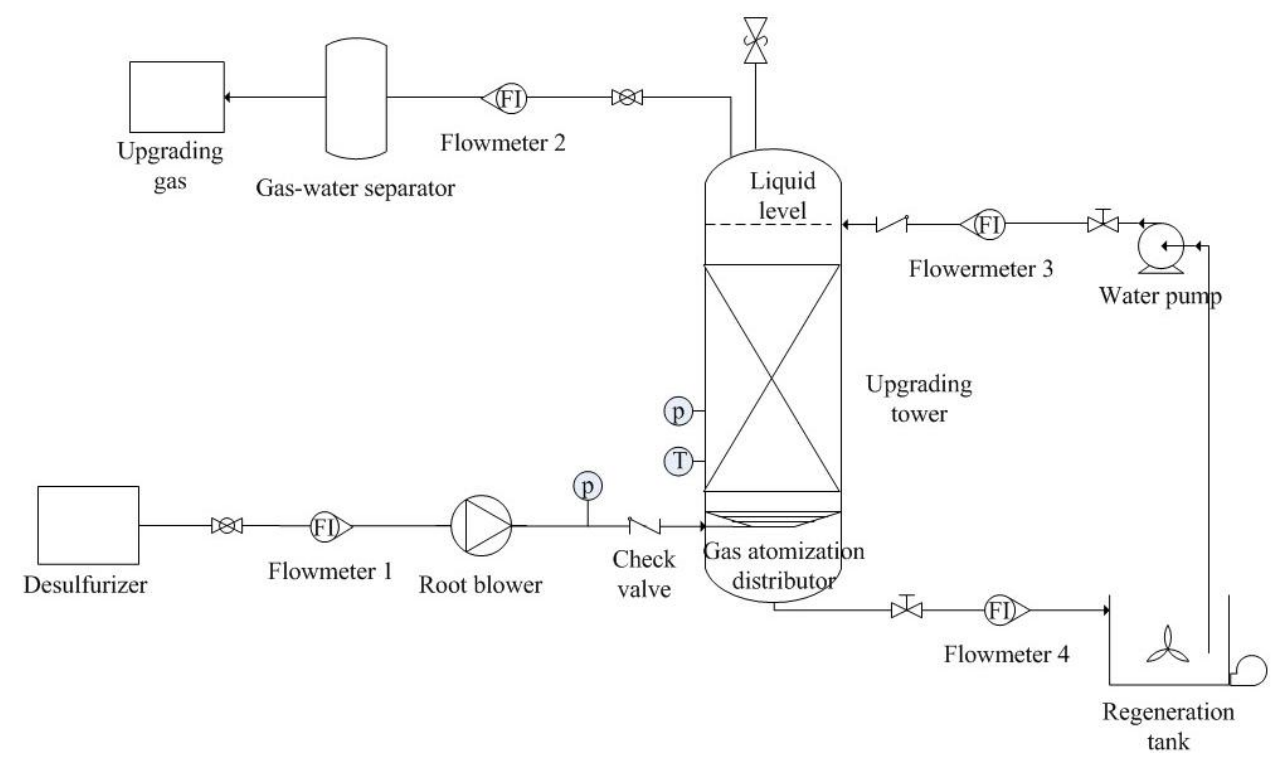

Figure 1. Upgrading process used in study 


\subsection{Function of gas atomization distributor}

The amount of substance of $\mathrm{CO}_{2}$ mass transfer per unit time is equal to the mass transfer area multiplied by the mass transfer rate. The equation shows as formula 3:

$m=\int_{s} N_{A} d s=S N_{A}$

In the formula $3, m$ is amount of substance of $\mathrm{CO}_{2}$ mass transfer per unit time; $S$ is interfacial area.

By increasing the contact area of gas-liquid two phases, the amount of substance of $\mathrm{CO}_{2}$ mass transfer can be improved in the process of absorption. By the gas atomization distributor, mainly the use of the rubber-plastic porous tube, biogas is scattered into a large number of small bubbles, which flows in the water in the form of bubble flow (Wang. 2012). A large number of dispersed bubbles increase the contact area of gasliquid, so the amount of substance of $\mathrm{CO}_{2}$ mass transfer is improve.

Gas atomization distributor consists of distribution head, connector, rubber-plastic porous tube (Chen et al. 2011) and supporting frame (Fig.2). Gas is distributed in the six tubes by distributor to shorten the length of single porous tube and reduce pressure loss. Distribution head and porous tube connect by the pipe joint. Porous tube is coiled in supporting frame and the tail of tube is closed. Supporting frame is fixed in the install of bottom of upgrading tower. In order to make bubbles be distributed in water uniformly, distributor is coneshaped in the depth direction (Zhang. 2011).

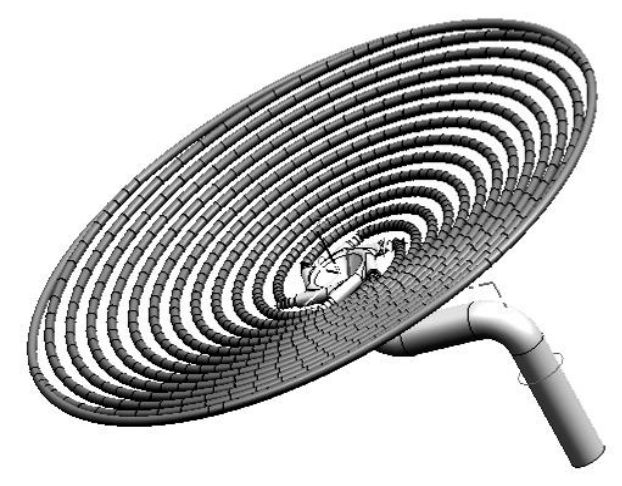

Figure 2. Gas atomization distributor

\subsection{Test procedures}

Inlet gas flow rate, outlet gas flow rate and water flow rate can be measured with flowmeters installed on the pipeline. The concentrations of $\mathrm{CH}_{4}$ and $\mathrm{CO}_{2}$ in biogas (before upgrading and after upgrading) are measured by the GX5-510 type infrared gas analyzer measurement. Y20 sample gas handling system is used in gas pretreatment to remove the impurities in the biogas and dry sample gas and ensure the accuracy of the measurement data. Test steps are as follows:

(1) Before test, record the weather and water temperature.

(2) Adjust the water level and leave some space in the top of upgrading tower.

(3) Open roots blower, adjust the frequency converter to $20 \mathrm{~Hz}$; observe the flowmeter; adjust the frequency converter to change the inlet gas flow to that we need and record the inlet gas flow.

(4) Measure concentrations of $\mathrm{CH}_{4}$ and $\mathrm{CO}_{2}$ of biogas at inlet.

(5) Open the water pump, observe the flow meter, adjust water flow rate of inlet and outlet to $7 \mathrm{~m}^{3} / \mathrm{h}$.

(6) Record the outlet gas flow. Wait for 15 minutes. When the instrument reading is stable, read the concentration of $\mathrm{CH}_{4}$ and $\mathrm{CO}_{2}$ biogas at outlet.

(7) Repeat the above steps, change frequency to change the inlet gas flow.

\section{RESULTS AND DISCUSSION}

\subsection{Influence of gas-water ratio}

At the water temperature of $3.5^{\circ} \mathrm{C}$, with the increase of gas water ratio, the curve is stable at the beginning and the fluctuation is not big (Fig. 3). The capacity of water absorbing $\mathrm{CO}_{2}$ is not reach saturated. When gas-water ratio increased to 2.2 or so, the curve starts to fall. It shows that the volume of biogas is too much. The excessive $\mathrm{CO}_{2}$ gas cannot be absorbed by water.

At the water temperature of $7^{\circ} \mathrm{C}$ and $11^{\circ} \mathrm{C}$, the analysis of the situation is similar to $3.5^{\circ} \mathrm{C}$, the difference is that curve starts to drop when the gaswater ratio is about 1.9 and 1.8 (Figs 4-5).

At water temperature of $15^{\circ} \mathrm{C}$ and $18^{\circ} \mathrm{C}$, the curve shows a downward trend on the whole along with the increase of the gas-water ratio (Figs 6-7). And when the gas-water ratio is $1.2 \sim 1.4$, the curve falls steeply.

At water temperature of $22^{\circ} \mathrm{C}$, the gas-water ratio is about 1.0 (Fig. 8).

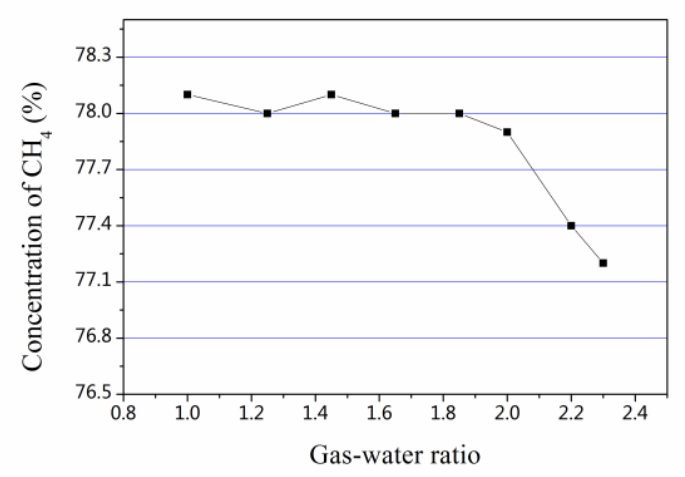

Figure 3. The concentration of $\mathrm{CH}_{4}$ in biogas after upgrading at different gas-water ratio (water temperature is $3.5^{\circ} \mathrm{C}$ ) 


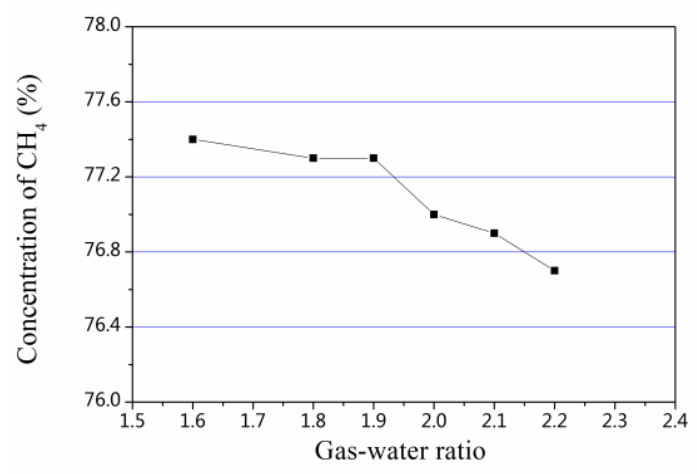

Figure 4. The concentration of $\mathrm{CH}_{4}$ in biogas after upgrading at different gas-water ratio (water temperature is $7^{\circ} \mathrm{C}$ )

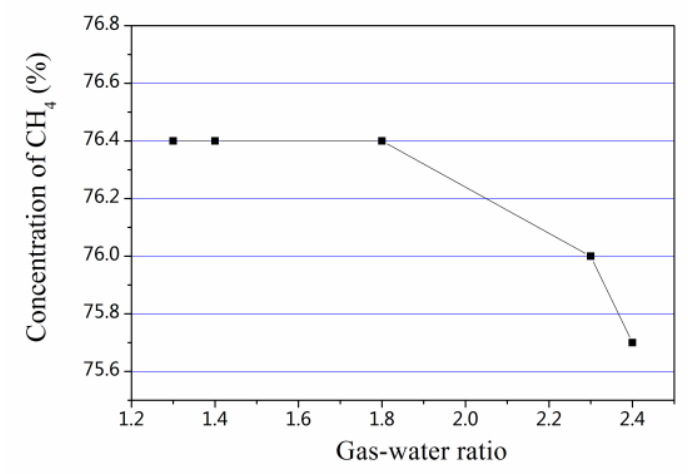

Figure 5. The concentration of $\mathrm{CH}_{4}$ in biogas after upgrading at different gas-water ratio (water temperature is $11^{\circ} \mathrm{C}$ )

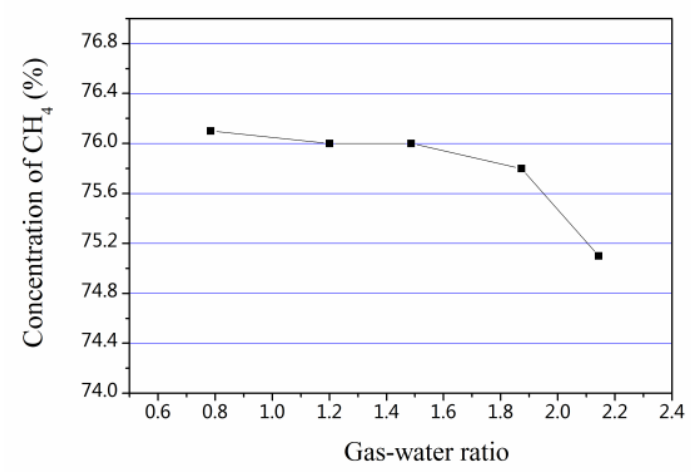

Figure 6. The concentration of $\mathrm{CH}_{4}$ in biogas after upgrading at different gas-water ratio (water temperature is $15^{\circ} \mathrm{C}$ )

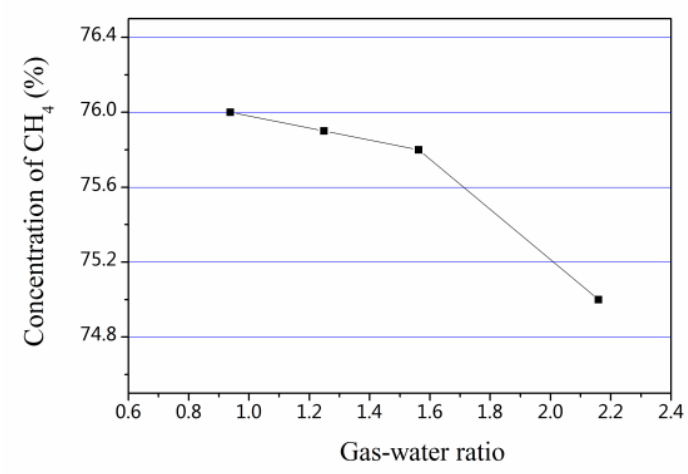

Figure 7. The concentration of $\mathrm{CH}_{4}$ in biogas after upgrading at different gas-water ratio (water temperature is $18^{\circ} \mathrm{C}$ )

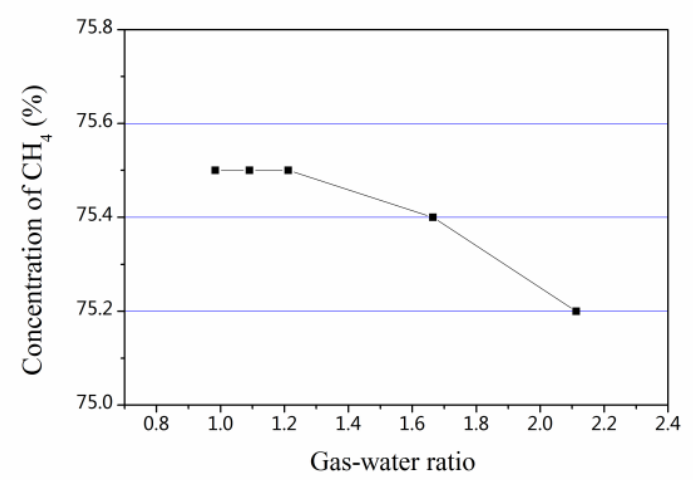

Figure 8. The concentration of $\mathrm{CH}_{4}$ in biogas after upgrading at different gas-water ratio (water temperature is $22^{\circ} \mathrm{C}$ )

\subsection{Influence of water temperature}

At atmospheric pressure, the water temperature has an obvious influence on the effect of biogas upgrading. As the gas-water ratio is same, it can be seen that the curve of the low temperature is significantly higher than that of high temperature (Figs 9-10). When the gas-water radio is 1.6, the curve of $\mathrm{CH}_{4}$ concentration shows a downward trend along with the increase of water temperature (Fig. 11).

When water temperature is less than $0^{\circ} \mathrm{C}$, water freezes and upgrading system can't work. However water temperature is above $25^{\circ} \mathrm{C}$, the ability of water absorbing $\mathrm{CO}_{2}$ drops greatly. So the appropriate water temperature is between 0 and $25^{\circ} \mathrm{C}$ in the system of biogas atomization upgrading with water scrubbing at atmospheric pressure.

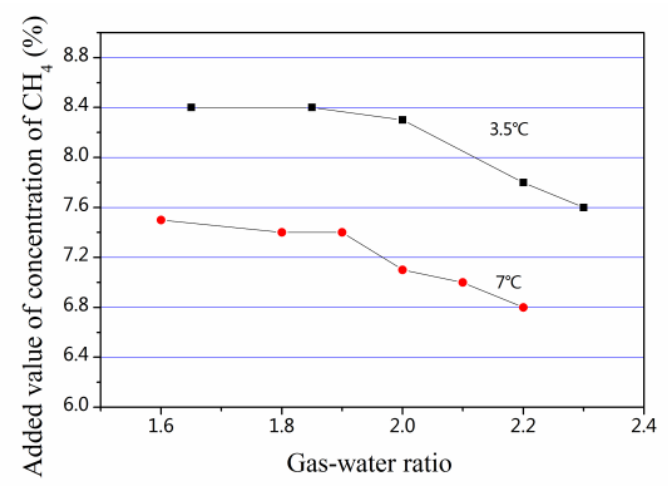

Figure 9. Comparison of effect of biogas upgrading at the same gas-ratio and different water temperature

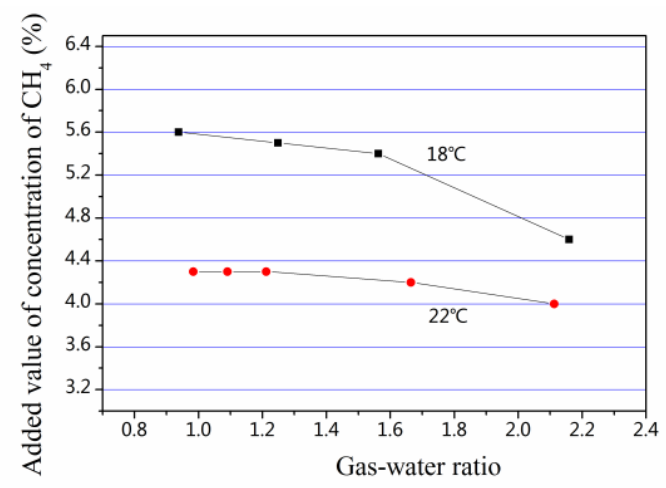

Figure 10. Comparison of effect of biogas upgrading at the same gas-ratio and different water temperature 


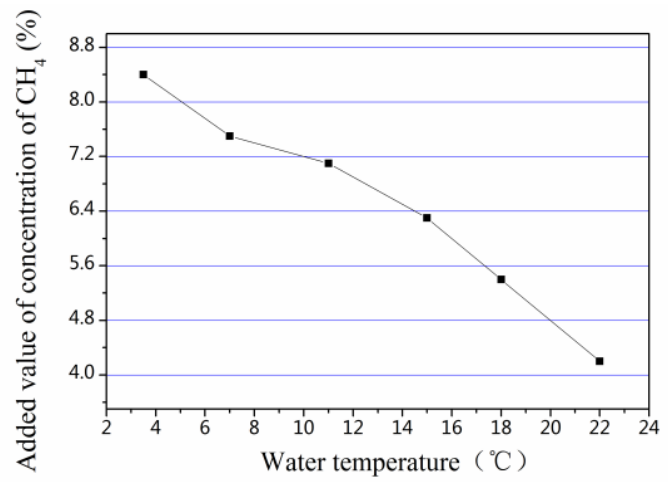

\subsection{Technological parameters}

Through a series of outdoor tests, we get the technological parameters of biogas upgrading system at different temperature (Table 2). Mainly includes the best gas-water ratio and effect of upgrading at different water temperature. The technological parameters are suitable for the biogas engineering whose processing is $6 \sim 20 \mathrm{~m}^{3} / \mathrm{h}$.

Figure 11. The concentration of $\mathrm{CH}_{4}$ of biogas after upgrading at different water temperature

Table 2. Technological parameters

\begin{tabular}{|c|c|c|c|c|}
\hline $\begin{array}{c}\text { Water } \\
\text { temperature }\left({ }^{\circ} \mathrm{C}\right)\end{array}$ & $\begin{array}{c}\text { Concentration of } \mathrm{CH}_{4} \text { and } \mathrm{CO}_{2} \\
\text { in biogas before upgrading }(\%)\end{array}$ & $\begin{array}{c}\text { The best gas- } \\
\text { water ratio }\end{array}$ & $\begin{array}{c}\text { Concentration of } \mathrm{CH}_{4} \text { and } \mathrm{CO}_{2} \\
\text { in biogas after upgrading }(\%)\end{array}$ & $\begin{array}{c}\text { Increase value of } \\
\text { concentration of } \mathrm{CH}_{4}(\%)\end{array}$ \\
\hline $0 \sim 5$ & $69.6,30.4$ & 2.2 & $78.0,22.0$ & $8.0 \sim 9.0$ \\
\hline $5 \sim 10$ & $69.9,30.1$ & $1.8 \sim 2.0$ & $77.4,22.6$ & $7.0 \sim 8.0$ \\
\hline $10 \sim 15$ & $69.9,30.1$ & $1.5 \sim 1.8$ & $76.4,23.6$ & $6.0 \sim 7.0$ \\
\hline $15 \sim 20$ & $70.4,29.6$ & $1.2 \sim 1.5$ & $76.0,24$ & $5.0 \sim 6.0$ \\
\hline $20 \sim 25$ & $71.2,28.8$ & $1.0 \sim 1.2$ & $75.4,24.4$ & $4.0 \sim 5.0$ \\
\hline
\end{tabular}

\subsection{Efficiency and energy consumption}

The efficiency of biogas upgrading is measured by $\mathrm{CO}_{2}$ removal rate and the solubility of $\mathrm{CO}_{2}$ in water. $\mathrm{CO}_{2}$ removal rate and solubility is larger, and the efficiency of system is higher. $\mathrm{CO}_{2}$ removal rate can be calculated by formula 4 :

$\eta=\frac{v_{i} c_{i}-v_{o} c_{o}}{v_{i} c_{i}} \times 100 \%$

In formula 4, $\eta$ is $\mathrm{CO}_{2}$ removal rate; $v_{i}$ is Inlet gas flow rate; $v_{o}$ is outlet gas flow rate; $c_{i}$ is concentration of $\mathrm{CO}_{2}$ at entrance; $c_{o}$ is concentration of $\mathrm{CO}_{2}$ at export.

The solubility of $\mathrm{CO}_{2}$ can be calculated by formula 5:

$S_{c}=\frac{v_{i} c_{i}-v_{o} c_{o}}{V_{m} v}$

In formula $5, S_{c}$ is the solubility of $\mathrm{CO}_{2}$ in water; $v$ is water flow rate; $V_{m}$ is molar volume of gas.

According to calculating, we can see that $\mathrm{CO}_{2}$ removal rate is higher and effect of biogas upgrading is better at low temperature. At the temperature of $3.5^{\circ} \mathrm{C}$, the $\mathrm{CO}_{2}$ removal rate reaches to $35 \%$ and the solubility of $\mathrm{CO}_{2}$ is $9.64 \times 10^{-3} \mathrm{~mol} / \mathrm{kg}$ in water. When temperature increases, the effect is not very ideal. The $\mathrm{CO}_{2}$ removal rate reaches only to $21 \%$ and the solubility of $\mathrm{CO} 2$ is $3.12 \times 10^{-3} \mathrm{~mol} / \mathrm{kg}$ in water at the temperature of $22^{\circ} \mathrm{C}$.

The energy consumptions of system main include roots blower and water pump. Because of space limitation, we didn't build regeneration tank and install blower air blower for regenerating water. Under the different temperature and the best gas water ratio, the energy consumption is shown in Table 3. As the water temperature is low, processing is large and energy consumption of processing per unit volume of biogas is low, it is about $0.23 \mathrm{~kW} \cdot \mathrm{h} / \mathrm{m}^{3}$. At the high water temperature, processing is small and energy consumption of processing per unit volume of biogas is high, it is about $0.35 \mathrm{~kW} \cdot \mathrm{h} / \mathrm{m}^{3}$.

For the system of biogas atomization upgrading with water scrubbing at atmospheric pressure, $\mathrm{CO}_{2}$ removal rate is low, but the corresponding energy consumption is low too. This system is suitable for the household biogas digester, which can increase concentration $\mathrm{CH}_{4}$ of biogas produced appropriately and improve the heat of combustion. In addition, the system could be also used as a pretreatment system of large-scale engineer of water scrubbing at high pressure. It can removal of $\mathrm{CO}_{2}$ in advance and reduce the pressure and processing of follow-up process. 
Table 3. $\mathrm{CO}_{2}$ removal rate, solubility of $\mathrm{CO}_{2}$ and energy consumption at the best gas-water radio

\begin{tabular}{|c|c|c|c|c|c|c|c|c|}
\hline $\begin{array}{c}\text { Water } \\
\text { temperature } \\
\left({ }^{\circ} \mathrm{C}\right)\end{array}$ & $\begin{array}{c}\text { Inlet gas } \\
\text { flow rate } \\
\left(\mathrm{m}^{3} / \mathrm{h}\right)\end{array}$ & $\begin{array}{c}\text { Out gas } \\
\text { flow rate } \\
\left(\mathrm{m}^{3} / \mathrm{h}\right)\end{array}$ & $\begin{array}{c}\text { Water } \\
\text { flow rate } \\
(\mathrm{m} / \mathrm{h})\end{array}$ & $\begin{array}{c}\text { Concentration of } \\
\mathrm{CO}_{2} \text { of inlet } \\
(\%)\end{array}$ & $\begin{array}{c}\text { Concentration of } \\
\mathrm{CO}_{2} \text { of outlet } \\
(\%)\end{array}$ & $\begin{array}{c}\eta \\
(\%)\end{array}$ & $\begin{array}{c}S_{c} \times 10^{-3} \\
(\mathrm{~mol} / \mathrm{L})\end{array}$ & $\begin{array}{c}\text { Energy } \\
\text { consumption } \\
\left(\mathrm{kW} \cdot \mathrm{h} / \mathrm{m}^{3}\right)\end{array}$ \\
\hline 3.5 & 14.3 & 12.7 & 7 & 30.4 & 22.1 & 35.43 & 9.64 & 0.23 \\
\hline 7 & 13.5 & 11.8 & 7 & 30.1 & 22.7 & 32.40 & 8.17 & 0.24 \\
\hline 11 & 12.8 & 11.5 & 7 & 30.7 & 23.6 & 30.93 & 7.47 & 0.26 \\
\hline 15 & 10.5 & 9.5 & 7 & 30.6 & 23.9 & 29.33 & 5.69 & 0.27 \\
\hline 18 & 9.2 & 8.5 & 7 & 29.6 & 24.1 & 24.78 & 4.01 & 0.31 \\
\hline 22 & 8.5 & 7.9 & 7 & 28.8 & 24.3 & 21.58 & 3.12 & 0.34 \\
\hline
\end{tabular}

\section{CONCLUSION}

1) The temperature is a key factor for affecting the effect of biogas upgrading at normal pressure, with the increase of temperature, the solubility of $\mathrm{CO}_{2}$ in water reduces gradually, the effect of upgrading becomes poor gradually.

2) Because of the use of gas atomization distributor, biogas is divided into a large number of small bubbles, which improves gas - liquid mass transfer rate and is beneficial to the $\mathrm{CO}_{2}$ dissolved in the water. The effect of biogas upgrading improves.

3) At certain water temperature, the appropriate selection of gas-water radio can save water and improve the processing of biogas. At low temperature, the best gas water ratio is 2.0 or so, and concentration of $\mathrm{CH}_{4}$ in biogas can improve $7 \%$ 8\%. At high temperature, the best gas water ratio is 1.2 or so, and concentration of $\mathrm{CH}_{4}$ of biogas can improve $4 \% \sim 5 \%$.

4) At low water temperature, energy consumption of processing per unit volume of biogas is about $0.23 \mathrm{~kW} \cdot \mathrm{h} / \mathrm{m}^{3}$. At high water temperature, energy consumption of processing per unit volume of biogas is about $0.35 \mathrm{~kW} \cdot \mathrm{h} / \mathrm{m}^{3}$.

5) The technological parameters of the biogas upgrading system are suitable for the biogas engineering whose processing is $6 \sim 20 \mathrm{~m}^{3} / \mathrm{h}$. This system is suitable for the household biogas digester and could be also used as a pretreatment system of large-scale engineer of biogas upgrading at high pressure.

\section{REFERENCES}

[1] Cheng Xiyu et al. 2008. Recent research progress in biogas fermentation process. The Chinese Journal of Process Engineering 8(3): 607 615 .

[2] Chen Xiang et al. 2010. Development of Biogas Purification and Upgrading Technologies for Producing Bio-Methane. Agricultural Engineering 2(7): 30 34 .

[3] Zheng Ge \& Zhang Quanguo. 2013. Review on biogas upgrading technologies for producing biomethane. Transaction of the Chinese Society of Agriculture Engineering 29(17): $1 \sim 8$.

[4] Ma Lili. 2009. Explorative research on the dynamic dissolution equilibrium of carbon dioxide-water system. Beijing: Beijing University of Chemical Technology.

[5] Song Shimo et al. 1992. Physical chemistry (Rudin). Beijing: Higer Education Press.

[6] Jia Shaoyi \& Chai Chengjing. 2013. Chemical Engineering Principles. Beijing: Higher Education Press.

[7] Wang Jing. 2012.Research on the Dynamic Behavior of Gas-Liqued Two-Phase Flow. Shanghai: Shanghai University Press.

[8] Chen Qidong \& Chen Qingzhang. 2010. Porous Pipe Dispersion Aquaculture Aerator Research based on Twophase Flow Characteristics. Applied Mechanics and Materials 33: 593 597.

[9] Zhang Xinrong. 2011. Biogas water-soluble purification equipment based on microporous pipe and it's $3 D$ Design. Jiangsu: Changshu Institute of Technology. 